\title{
On being a neurologist in Italy at the time of the COVID-19 outbreak
}

Anna Bersano, MD, PhD, and Leonardo Pantoni, MD, PhD

Neurology ${ }^{\circledR}$ 2020;94:905-906. doi:10.1212/WNL.0000000000009508

Italy is facing its fifth week of crisis due to the Coronavirus disease (COVID-19) outbreak, with affected patients and deaths near to 70,000 and 6,000, respectively, ${ }^{1}$ numbers that are increasing every day. Whether government imposition of quarantines, travel bans, and lockdown throughout the country will have effect in the next weeks in limiting the spreading of this disease has still to be seen. Meanwhile, a great spirit of sacrifice is required to health care personnel, and authorities have to manage resource allocation to rapidly increase the number of intensive care beds to assist patients with COVID-19. ${ }^{2}$ Although operating rooms and a number of wards have been turned into dedicated intensive units, beds and resources are hardly sufficient to satisfy the needs of so many simultaneously critically ill patients. ${ }^{3,4}$ Notably, among infected people, about $10 \%$ are health workers, and their number is increasing, also due to the scarcity of efficacious protective measures.

In this scenario, Italian neurologists are facing 2 different challenges. First, given the increasing number of COVID-19 cases, they have to deal with patients with neurologic complications from the disease. Neurologic disturbances such as loss of consciousness, headache, seizures, ageusia, hyposmia, dysphagia, and muscle pain are being increasingly reported in patients with COVID-19. ${ }^{5}$ Part of these signs and symptoms may be attributed to cerebral hypoxia due to pulmonary failure. However, it has been hypothesized that COVID-19 can invade the CNS, based on what is known about the severe acute respiratory syndrome (SARS) and Middle East respiratory syndrome viruses and the fact that angiotensin-converting enzyme 2 receptors, the functional receptor for SARS-CoV-2, are found in the central and peripheral nervous system and skeletal muscle. ${ }^{6-8}$ Like other respiratory viruses, COVID-19 may enter the CNS through hematogenous or retrograde neuronal routes, although there is increasing evidence that COVID-19 may also invade peripheral nerve terminals. ${ }^{6,7}$ Therefore, neurologists should suspect a COVID-19 infection in patients with neurologic disturbances and treat the disease's neurologic complications.

A second relevant challenge for Italian neurologists is due to the indirect consequences of the focus that the Italian health care system and media have put on the COVID-19 emergency. A great reorganization of the entire public health system is underway in many parts of Italy (of note, the health system is regionalized in Italy, and each region has great autonomy to make health care-related decisions). ${ }^{4}$ In many Italian regions, hospitals have been divided into COVID+ and COVID-free ones; several stroke units and neurointensive care units have been reorganized or even closed; and many neurologists have been reallocated to assist patients with COVID-19. These measures have had a major impact on the organization of the usual emergency networks for myocardial infarction, stroke, and major trauma. The new organization centralizes stroke care so that patients with stroke will receive acute treatment and hospitalization in a limited number of stroke units and hospitals. ${ }^{9}$ This system is different from the current hub and spoke organization, and it cannot be seen as a typical mother-and-ship model because patients will no longer be transferred back to the spokes because these are currently shut down or they have been turned into COVID-19 wards. When this model was proposed and implemented a few weeks ago in the Lombardia region, neurologists feared that these few hub centers would rapidly fill up with patients, leading to a collapse of the system because of the

\author{
Correspondence \\ Dr. Bersano \\ anna.bersano@gmail.com
}

\section{MORE ONLINE}

COVID-19 Resources

For the latest articles, invited commentaries, and blogs from physicians around the world

NPub.org/COVID19 
limited availability of beds and personnel. Surprisingly, this has not happened so far, as the number of patients needing acute treatment for vascular, cardiac, and neurologic events seems to have decreased considerably in the last few weeks.

The phenomenon has been seen throughout Italy, and it is even more surprising considering that many patients with COVID-19 have high D-dimer levels and may be at a higher risk of cerebrovascular diseases. ${ }^{5}$ Italian neurologists are wondering what are the reasons for this and hypothesize that patients with TIA or mild strokes remain home because of fear about going to the hospital during the outbreak and that patients with very severe strokes and those who had preexisting disability are also left at home. Another possible explanation is that patients with acute neurologic events and severe respiratory distress are not recognized to have a concurrent stroke. Of course, all these hypotheses will have to be studied, but if these situations are true, we may expect more patients with postacute complications and long-term disability due to the lack of appropriate acute management and implementation of secondary stroke prevention interventions.

In addition, Italian neurologists, and especially their patients, are affected by the suspension or decrease of nonurgent medical visits and surgical interventions. This situation affects patients with chronic neurologic diseases such as epilepsy, multiple sclerosis, and movement disorders. In addition, access to rehabilitation treatments is limited, both in the inpatient (because rehabilitation beds are now used for patients with respiratory problems) and outpatients settings (whose activity was also heavily reduced). Who should assist these patients, how to treat them, and whether this policy is acceptable for the health system are at present unclear.
All these issues mean that the COVID-19 pandemic will negatively affect the care of patients with neurologic conditions. How big will this impact be is not yet known, but neurologists all over the world need to be prepared for it.

\section{Study funding}

No targeted funding reported.

\section{Disclosure}

The authors report no disclosures relevant to the manuscript. Go to Neurology.org/ $\mathrm{N}$ for full disclosures.

\section{Publication history}

Received by Neurology March 26, 2020. Accepted in final form March 30, 2020.

\section{References}

1. COVID-19 Information and Resources for JHU inhub.jhu.edu/novel-coronavirus-information[online]. Available at: coronavirus.jhu.edu/map.html. Accessed March 25, 2020.

2. Remuzzi A, Remuzzi G. COVID-19 and Italy: what next? Lancet 2020;30627-30629, pii: S0140-6736.

3. Rosenbaum L. Facing Covid-19 in Italy - ethics, logistics, and therapeutics on the epidemic's front line. N Engl J Med Epub 2020 Mar 18.

4. Spina S, Marrazzo F, Migliari M, Stucchi R, Sforza A, Fumagalli R. The response of Milan's Emergency Medical System to the COVID-19 outbreak in Italy. Lancet 2020; 395:e49-e50.

5. Mao L, Wang M, Chen S, et al. Neurological manifestations of hospitalized patients with COVID-19 in Wuhan, China: a retrospective case series study. MedRxiv. doi: 10.1101/2020.02.22.20026500.

6. Li YC, Bai WZ, Hirano N, et al. Neurotropic virus tracing suggests a membranouscoating-mediated mechanism for transsynaptic communication. J Comp Neurol 2013;521:203-212.

7. Baig AM, Khaleeq A, Ali U, Syeda H. Evidence of the COVID-19 virus targeting the CNS: tissue distribution, host-virus interaction, and proposed neurotropic mechanisms. ACS Chem Neurosci 2020. doi:10.1021/acschemneuro.0c00122.

8. Hamming I, Timens W, Bulthuis ML, Lely AT, Navis G, van Goor H. Tissue distribution of ACE2 protein, the functional receptor for SARS coronavirus. A first step in understanding SARS pathogenesis. J Pathol 2004;203:631-637.

9. Available at: regione.lombardia.it/wps/wcm/connect/5e0deec4-caca-409c825b-25f781d8756c/DGR+2906+8+marzo+2020.pdf?MOD$=$ AJPERES \&CACHEID=ROOTWORKSPACE-5e0deec $4-\mathrm{caca}-409 \mathrm{c}-825 \mathrm{~b}-$ 25f781d8756c-n2.vCsc. Accessed March 25, 2020. 


\section{Neurology}

\section{On being a neurologist in Italy at the time of the COVID-19 outbreak Anna Bersano and Leonardo Pantoni}

Neurology 2020;94;905-906 Published Online before print April 3, 2020

DOI 10.1212/WNL.0000000000009508

This information is current as of April 3, 2020

Updated Information \&
Services

References

Citations

Permissions \& Licensing

Reprints including high resolution figures, can be found at: http://n.neurology.org/content/94/21/905.full

This article cites 5 articles, 1 of which you can access for free at: http://n.neurology.org/content/94/21/905.full\#ref-list-1

This article has been cited by 2 HighWire-hosted articles: http://n.neurology.org/content/94/21/905.full\#\#otherarticles

Information about reproducing this article in parts (figures,tables) or in its entirety can be found online at:

http://www.neurology.org/about/about_the_journal\#permissions

Information about ordering reprints can be found online:

http://n.neurology.org/subscribers/advertise

Neurology ${ }^{\circledR}$ is the official journal of the American Academy of Neurology. Published continuously since 1951, it is now a weekly with 48 issues per year. Copyright () 2020 American Academy of Neurology. All rights reserved. Print ISSN: 0028-3878. Online ISSN: 1526-632X.

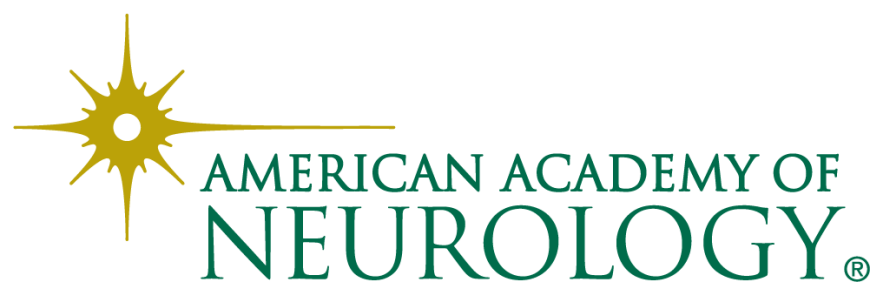

